\title{
Remediation of hexavalent chromium and selenium using the mineral ettringite
}

\author{
REBECCA RAE*, CAROLINE KiRK
}

Dept of Chemistry, University of Edinburgh, Edinburgh,UK

(*correspondence: rebecca.rae@ed.ac.uk)

Ettringite $\left(\mathrm{Ca}_{6}\left[\mathrm{Al}(\mathrm{OH})_{6}\right]_{2}\left(\mathrm{SO}_{4}\right)_{3} .26 \mathrm{H}_{2} \mathrm{O}\right)$ is an important hydration product of Portland cement. It also occurs naturally, being found in Germany and Northern Ireland. It has a well characterised structure which consists of columns of composition $\mathrm{Ca}_{3}\left[\mathrm{Al}(\mathrm{OH})_{6} .12 \mathrm{H}_{2} \mathrm{O}\right]^{3+}$ with sulfate $\left(\mathrm{SO}_{4}\right)^{2-}$ and the remaining water molecules in channels. Ettringite has been shown to accommodate other cations $\left(\mathrm{Fe}^{3+}, \mathrm{Ga}^{3+}\right)$ on the aluminium sites [1] and other oxyanions $\left(\mathrm{NO}_{3}{ }^{-}, \mathrm{CO}_{3}{ }^{2-}\right)$ in place of the sulfate anions in the channels [2].

The ability of the structure to accommodate a wide range of different ions of both size and charge, gives it the potential for use in waste remediation. For example, aluminium present in wastewater from the aluminium anodizing industry has been successfully removed using an ettringite precipitation method [3]. This study is particularly concerned with the oxyanions $\mathrm{CrO}_{4}{ }^{2-}$ and $\mathrm{SeO}_{4}{ }^{2-}$. These contain the elements chromium and selenium in their hexavalent oxidation state. When in this oxidation state they are both harmful to human health and the environment. The presence of hexavalent chromium in public water streams is mostly caused by runoff from nearby industry, while hexavalent selenium is present in mine waste and fly ash waste (from chimneys of coal power stations).

A study investigating the formation of ettringite-type phases where the sulfate group has been replaced with other oxyanions $\left(\mathrm{CrO}_{4}{ }^{2-}, \mathrm{SeO}_{4}{ }^{2-}\right)$ has been carried out in order to test the viability of using these phases for waste remediation. Ettringite-type phases $\mathrm{Ca} 6\left[\mathrm{Al}(\mathrm{OH})_{6} \cdot 12 \mathrm{H}_{2} \mathrm{O}\right]_{2}\left(\mathrm{XO}_{4}\right)_{3}\left(\mathrm{H}_{2} \mathrm{O}\right)_{2}$; $\mathrm{X}=\mathrm{Cr}$, Se have been successfully synthesised using precipitation methods and the time dependence of their formation has also been investigated. Preliminary data shows that the ettringite-type phase starts to form within one hour. Solid solution behaviour between the parent sulfate ettringite phase and these analogue phases $\mathrm{Ca}_{6}\left[\mathrm{Al}(\mathrm{OH})_{6}\right]_{2}\left(\mathrm{SO}_{4}\right)_{3}$ $\mathrm{x}\left(\mathrm{XO}_{4}\right)_{\mathrm{x}} \cdot 26 \mathrm{H}_{2} \mathrm{O} ; \mathrm{X}=\mathrm{Cr}, \mathrm{Se}$ has also been shown. Characterisation of the formed phases has been carried out using Powder X-ray diffraction and FTIR spectroscopy.

[1] Norman et al. (2013) Solid State Sci 25, 110-117. [2] Pollmann et al. (1989) Neues Jahrbuch Miner. Abh. 160, 133-158. [3] Alvarez-Ayuso \& Nugteren (2005) Water Res 39, 65-72. 